\title{
Case report: \\ BLOWOUT FRACTURE COMPLEX TYPE
}

\section{Fauzi Helmi, Boedy Setya Santoso}

Department of Otorhinolaryngology Head and Neck Surgery, Faculty of Medicine, Universitas Airlangga, Dr. Soetomo Hospital, Surabaya, Indonesia

\section{ABSTRACT}

Functional problems and appearance may emerge if careful therapy is not applied in orbital fracture caused by maxillofacial trauma. Recently, the focus of fracture management on fragment fixation most possibly uses anatomy approach. The management of blowout fracture should be overcome by involving several departments. First, identification was carried out in emergency room and then it is consulted to occuloplasty and maxillofacial trauma surgeon. Multidisciplinary management will provide better outcome to retrieve face structural function and improve the appearance. We reported two cases of blowout fracture complex in Dr. Soetomo Hospital, Surabaya, Indonesia, done by Plastic Reconstruction Division of ORL-HNS Department in collaboration with Plastic Reconstruction Division of Ophthalmology Department. In the first case, a 64-year-old female was consulted by Plastic Reconstruction Division of Ophthalmology Department with diagnosis of right orbital adnexal injury, open eye globe injury, scleral laceration, and blowout fracture. In the second case, a 37-year-old male came to Plastic Reconstruction Division of ORL HNS Department, consulted by Plastic Reconstruction of Ophthalmology Department with diagnosis of left cornea and scleral laceration, left full thickness laceration palpebral at 1/3 nasal inferior, rupture of lacrimal canal, and blowout fracture. These cases of blowout fracture with rim orbita fracture complex type were managed well by Plastic Reconstruction Division of ORL-HNS and Plastic Reconstruction Division of Ophthalmology Department. It is apparent that multidisciplinary management was required for optimum outcome.

Keywords: Orbital fracture; maxillofacial trauma; blowout fracture type; plastic reconstruction; multidisciplinary management

\section{ABSTRAK}

Masalah dan penampilan fungsional dapat muncul jika terapi yang cermat tidak diterapkan pada fraktur orbital yang disebabkan oleh trauma maksilofasial. Baru-baru ini, fokus manajemen fraktur pada fiksasi fragmen paling mungkin menggunakan pendekatan anatomi. Manajemen fraktur blowout harus diatasi dengan melibatkan beberapa departemen. Pertama, identifikasi dilakukan di ruang gawat darurat dan kemudian dikonsultasikan dengan ahli bedah trauma okuloplasti dan maksilofasial. Manajemen multidisiplin akan memberikan hasil yang lebih baik untuk mengambil fungsi struktural wajah dan meningkatkan penampilan. Kami melaporkan dua kasus kompleks fraktur blowout di Rumah Sakit Dr. Soetomo, Surabaya, Indonesia, yang dilakukan oleh Divisi Rekonstruksi Plastik Departemen ORL-HNS bekerja sama dengan Divisi Rekonstruksi Plastik Departemen Oftalmologi. Dalam kasus pertama, seorang wanita berusia 64 tahun dikonsultasikan oleh Divisi Rekonstruksi Plastik Departemen Oftalmologi dengan diagnosis cedera adneksa orbital kanan, cedera bola mata terbuka, laserasi skleral, dan fraktur semburan. Dalam kasus kedua, seorang laki-laki berusia 37 tahun datang ke Divisi Rekonstruksi Plastik Departemen ORL HNS, dikonsultasikan oleh Departemen Rekonstruksi Plastik Departemen Oftalmologi dengan diagnosis kornea kiri dan laserasi skleral, laser palpebra kiri dengan ketebalan penuh pada 1/3 hidung lebih rendah, pecahnya kanal lakrimal, dan fraktur blowout. Kasus-kasus blowout fracture dengan tipe kompleks fraktur orbita ini dikelola dengan baik oleh Divisi Rekonstruksi Plastik ORL-HNS dan Divisi Rekonstruksi Plastik Departemen Oftalmologi. Jelas bahwa manajemen multidisiplin diperlukan untuk hasil yang optimal.

Kata kunci: Fraktur orbital; trauma maksilofasial; jenis blowout fracture; rekonstruksi plastik; manajemen multidisiplin

\section{Correspondence:}

pISSN:2355-8393 • eISSN: 2599-056x • doi: http://dx.doi.org/10.20473/fmi.v55i1.12564

- Fol Med Indones. 2019;55:74-81 • Received 10 May 2017 • Accepted 24 Aug 2017

- Open access under CC-BY-NC-SA license • Available at https://e-journal.unair.ac.id/FMI/

\section{INTRODUCTION}

Maxillofacial trauma can cause orbital fracture and if not taken care well may cause functional problems and appearance. Lately, management of fracture focus on fragment fixation with most possible anatomy approach. Blowout fracture was introduced first by Lang in early 1990. Blowout fracture is a clinical syndrome that signs by orbital wall fracture. Orbital wall fracture may happen with or without orbital rim fracture. Orbital wall 
fracture without orbital rim fracture is called pure blowout fracture. Fracture that involves orbital rim is known as impure blowout fracture which classified into some types according to the location of the orbital rim involved, which are orbitozigomatic type, naso-orbitoethmoid (NOE), and complex type (Balasubramanian 2010).

Management of blowout fracture can be done by some departments. First identification is in emergency room, after treat the emergency then it will need consultation to occuloplasty and maxillofacial trauma surgeon. Multidiscipline management will give better result to retrieve face structural function and improve the appearance (Humphrey \& Kriet 2014).

This paper will discuss 2 case reports that contain managements of blowout fracture complex type at Dr. Soetomo hospital Surabaya done by Plastic reconstruction division of ORL-HNS department join with Plastic reconstruction division of Ophthalmology department.

\section{CASE REPORT}

\section{Case 1}

A 64-year-old female was consulted by Plastic reconstruction division of Ophthalmology department with diagnosis of right orbital adnexal injury, open eye globe injury, scleral laceration, and blowout fracture. She had history of falling from motorcycle 6 days before admitted to the hospital, her right side of the face hit the helmet that she held at the time, so her right skull cracked. Since that time, the patient could not see with her right eye. Epistaxis from right nostril and blood came out from the mouth when she fell. No blocking nose was found and the patient still could open the mouth.

Local state revealed deformity of nasal bone to the left with crepitation between nasal bone and right maxilla bone, laceration of superior and inferior right palpebra with ecchymosis. Anterior rhinoscopy found septal deviation to the left (Fig. 1).

Maxillofacial 3D CT-Scan at Dr. Soetomo hospital at May 10, 2016 showed blowout fracture of right orbita, vitreous, choroidal and preseptal hemorrage with suspicious avulsion of right optical nerve. Complete fracture of right zygomatic arch, right multiple lamina papyracea, nasal bone, nasal septal deviation, frontal, ethmoid, sphenoid, and right maxilla hematosinus (Image 2). Thorax x-ray revealed heart and lung within normal limit.

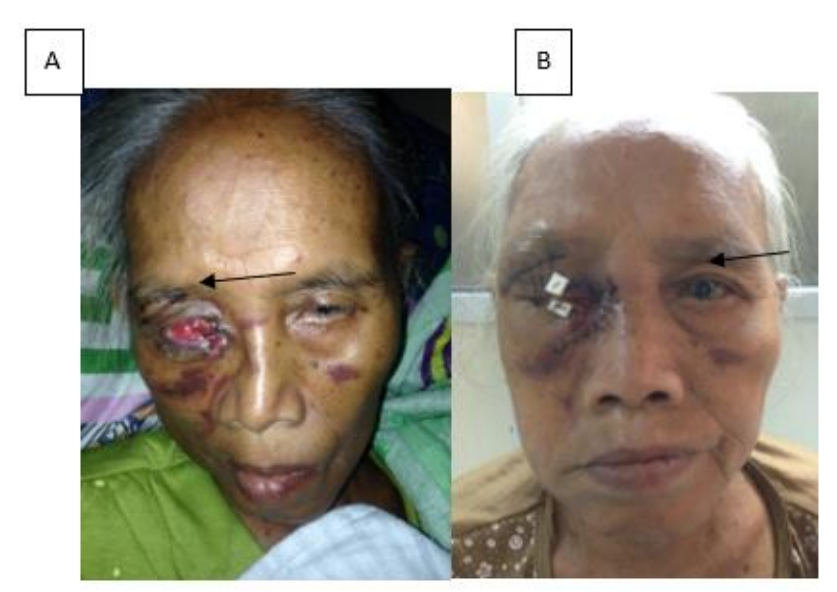

Fig. 1. (A) Six days after fell from motorcycle, palbebra laceration, ecchymosis and nasal bone deformity (arrow). (B) Two days after operation, nasal bone straightened, suture at infraorbital region and right frontozigomatic suture.

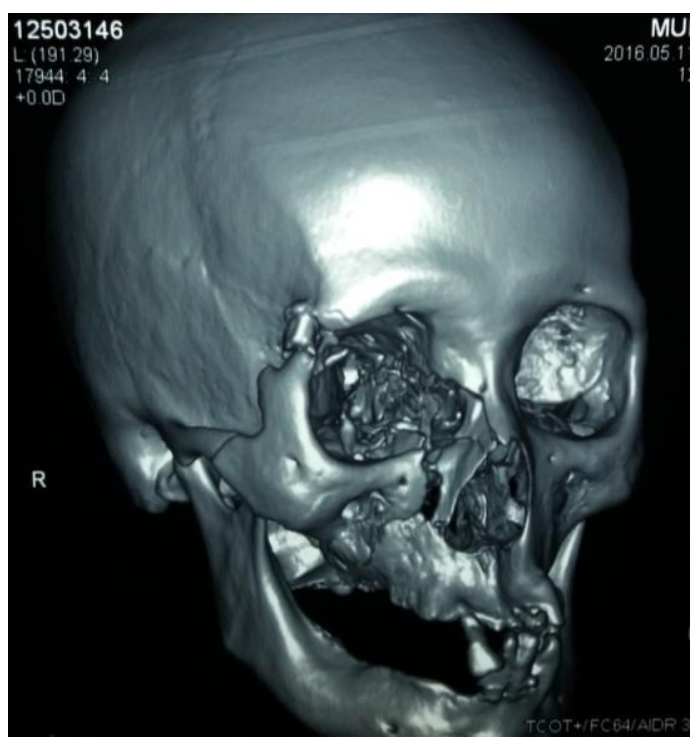

Fig. 2. Maxillofacial 3D CT-Scan. Blowout fracture complex type at right orbital wall. Arrow shows fracture at frontozygomatic, fracture of zygomaticarch (star), multiple fracture of lamina papyracea, nasal bone, and frontomaxillary (circle).

Patient was diagnosed with right blowout fracture with orbital wall fracture complex type, right orbita adnexal injury, open globe injury, scleral laceration, frontal, ethmoid, sphenoid, and right maxilla hematosinus. Patient was planned for open reduction and internal fixation using mini plate by Plastic reconstruction division of ORL-HNS and exploration of right orbital, suture of the scleral and superior full thickness 
palpebral, and tarsorraphy by Plastic reconstruction division of Ophthalmology department.

Operation was done on May 17, 2016. Plastic reconstruction division of Ophthalmology department performed exploration of right orbital and found laceration at scleral and superior palpebral. Scleral and superior palpebral were sutured, then tarsorraphy was done (Image 3). The patient was advised to have evisceration done and fat taken from gluteus will be implantation in eyeball to prevent atrophy so the appearence would be better, but the patient refused.

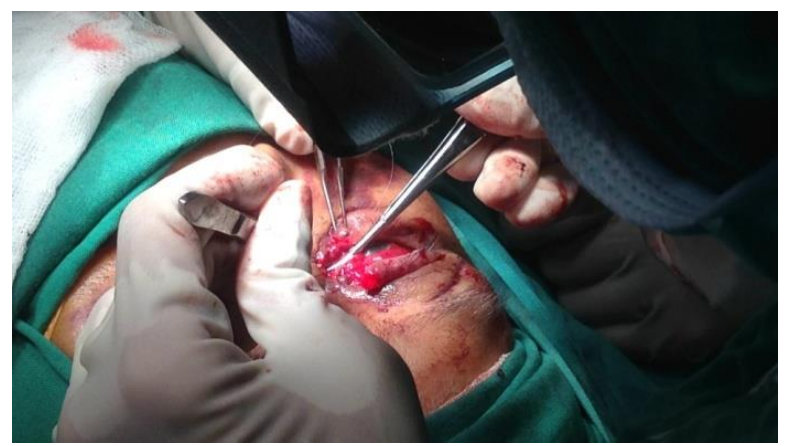

Fig. 3. Operation started with exploration of right orbital, suturation of lacerated scleral and superior palpebral, and tarsorraphy.

Operation was continued by Plastic reconstruction division of ORL-HNS. After infiltration was done, subtarsal incision at infraorbital region was performed according to right eye curve line. Incision was deepened until bone exposed and fracture could be explored. Discontinuity at frontomaxillary region (procesus frontal os maxilla) was exposed to medial until discontinuity with nasal bone was seen.

Incision was continued as to right eye brow incision, widened $2-3 \mathrm{~cm}$ to lateral and deepened until fracture line was seen (frontozygomatic). Zygoma arch fracture was not planned for mini plate because of its stability. When both of fractures were identified, reduction was performed. Malaligned/displaced nasal bone was mobilized first with nasal elevator or Walsham forcep, and put back to the original position. Dislocated nasal septum was also put back to its former position at maxillary crest and manipulated in a way with Asch forcep so it could be straightened. After reduction of nasal and maxilla bone, reduction of frontoziyomatic area was performed. Then mini plate was screwed at infraorbital region to unify nasal bone and maxilla fragments, using mini plate size 1,5 mm (Image 4). The same size mini plate was also screwed at frontozygomatic region (Image 5). Bonewax was applied in both areas.
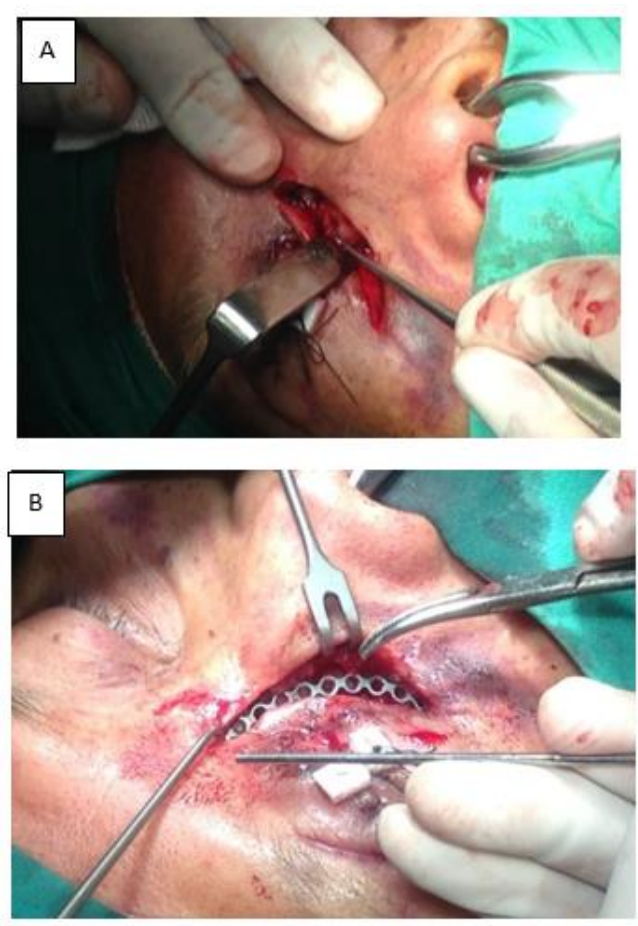

Fig. 4. (A) Subtarsal incision according to right eye curve line was deepened until periost and fracture was identified, discontinuity of nasal bone, procesus frontal os maxilla and maxilla. (B) Reduction of nasal bone and septum, reposition of nasal bone, maxilla, and zygoma, then fixated with miniplate.

Ceftriaxone 1 gram twice a day intravenously post operation, and also levofloxacine eye drop 6 drops once daily. Third day after post operation wound care was done, wound was starting to heal, tarsorraphy was opened and patient was scheduled for naso-endoscopy evaluation in the fifth day. It resulted straightening septum with no secret nor blood clot. Skull AP-Lateral $\mathrm{X}$-ray revealed that mini plate was placed among bone discontinuity. Patient was discharged at the sixth day with cefixime $100 \mathrm{mg}$ twice a day. At first follow up visit (a week after operation) wound healed well, symmetrical face, no hypoesthesia at right side of the face, eyelid could be opened but not maximal. All sutured were taken off at the second visit, patient already could open eyelid wider, however still not maximal, orbital movement was still limited.

\section{Case 2}

A 37 year old male came to Plastic reconstruction division of ORL HNS department on May 24th 2016, he was consulted by Plastic reconstruction of Ophthalmology department with diagnosis of left cornea and scleral laceration, left full thickness laceration 
palpebral at $1 / 3$ nasal inferior, rupture of lacrimal canal, and blowout fracture.

From history taking, the patient got hit on the left side of his face a week before coming to the hospital and he could not see through his left eye since then. The patient lost his consciousness at that moment. Physical examination found crepitation and deformity of nasal bone to the right and ecchymosis at left side of the face. Patient could not open his mouth, no malcocclution nor hypoesthesia, and there was situational suture at left inferior palpebral. Anterior rhinoscopy showed no nasal deviation, neither blood clot (Fig. 6).
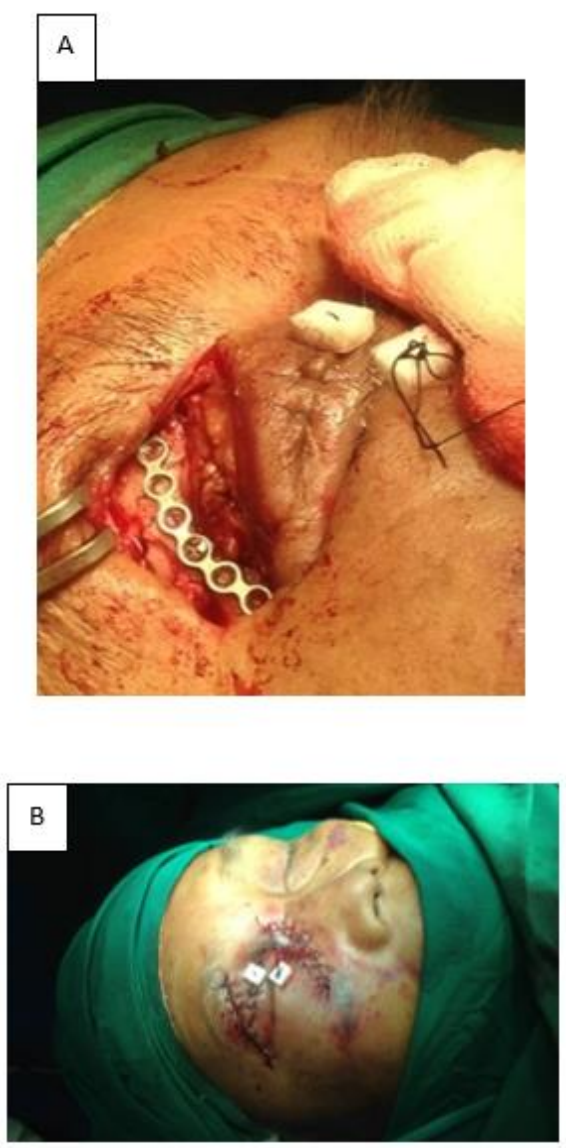

Fig. 5. (A) Eye brow incision to have access to frontozygomatic suture, fixated using mini plate. (B) After suturation.

Maxilofacial 3D CT scan was performed because of suspicious blowout fracture. The result of 3D CT-scan on May 20th 2016 revealed complete fracture of left zygomatico arch, nasal bone, nasal septal deviation, left maxilla and ethmoid hematosinus (Fig. 7).

Patient was also diagnosed with blowout fracture complex type with left corneal and scleral laceration, left full thickness laceration of the palpebral at $1 / 3$ nasal inferior, and rupture of lacrimal canal. Patient was planned to have open reduction and internal fixation using mini plate size $1,5 \mathrm{~mm}$ by Plastic reconstruction division of ORL HNS department and left orbital evisceration, fat flap from gluteus, sticth the palpebra laceration, and lacrimal canal repair by Plastic reconstruction of Ophthalmology department

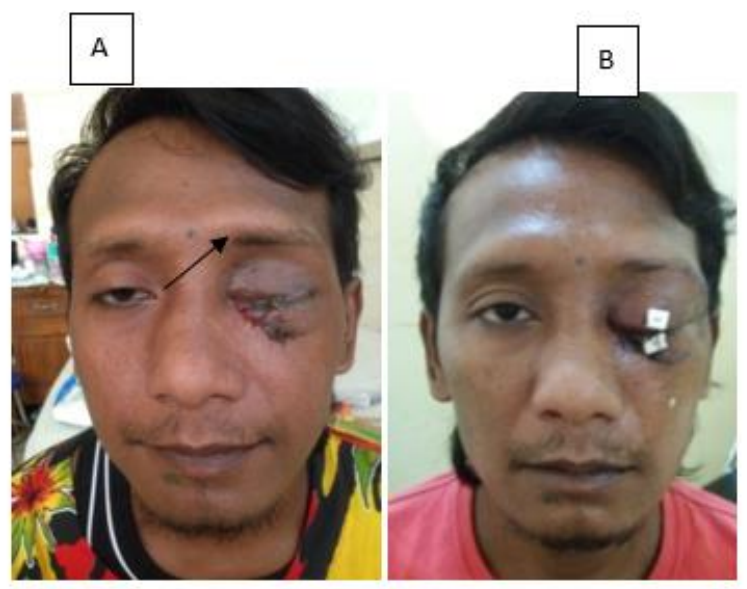

Fig. 6. (A) Two weeks after got hit with wood, palpebral laceration, ecchymosis, and nasal bone deformity (arrow). (B) Two days post operation.

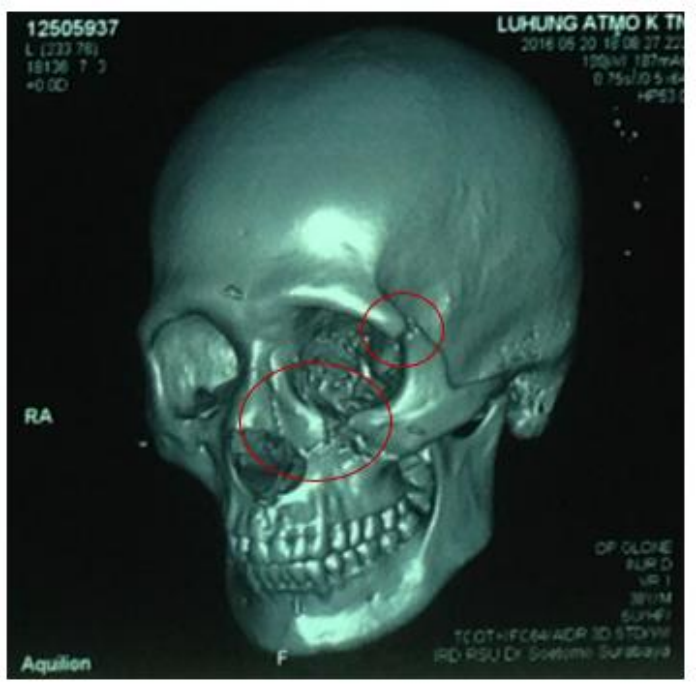

Fig. 7. Maxillofacial 3D CT scan.

Operation started by infiltrating lidocain-adrenalin $1: 200.000$, then left eye brow incision was done to 2-3 $\mathrm{cm}$ to lateral side. Fracture identification showed, fracture line at frontozigomatic suture. After that, 
infiltration and incision at infraorbita region, with subtarsal incision was deepened until fracture at zigomaticmaxillary suture identified. Reposition and fixation with mini plate was performed. At first platting at zigomaticmaxillary suture, then platting at frontozigomatic suture, bonewax was applied at platting site before suture was done (Fig. 8).
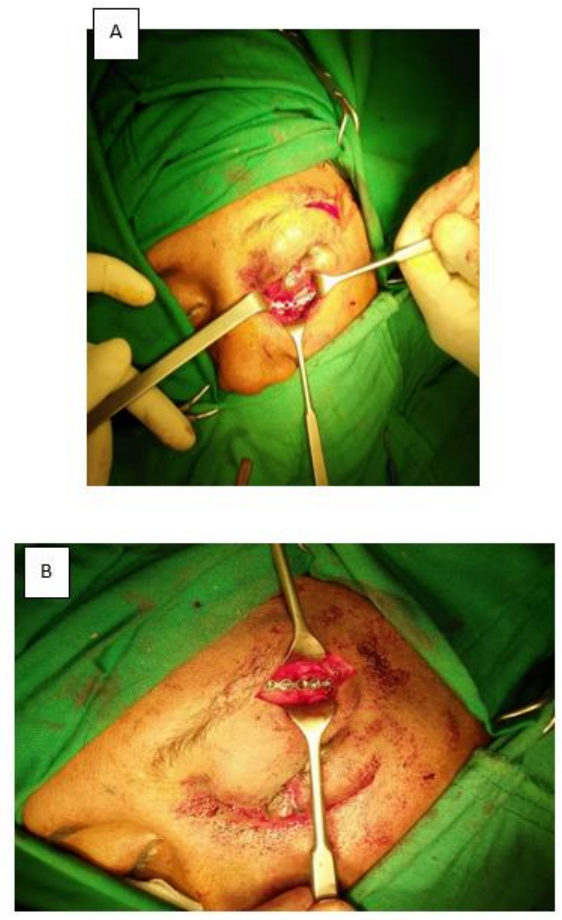

Fig. 8. (A) Mini plate was screwed at infraorbital. (B) Mini plate was screwed at superior of frontozygomatic suture.

Patient was given cefotaxime 1 gram twice a day intravenously and levofloxacine eye drop 6 drops once daily pasca operation. Skull AP Lateral x-ray showed mini plate on fracture line (Fig. 9). Evaluation one week pasca operation using naso-endoscopy revealed no blood clot inside nasal cavity. Two weeks after operation wound healing was going well and patient could open palpebral but not maximal, he also can do eye movement but fixated.

\section{DISCUSSION}

Maxillofacial trauma is caused generally by traffic accident, fell from height, industrial accident, domestic violence, criminal that caused sharp or blunt trauma, sport accident, and gun shot. It was affected geographical condition, socio economic status, cultural characteristic, and development era. Traffic accident is the most possible cause, especially in developing countries, while crime between people is the major cause in developed countries (Kentjono 2013).

Epidemiology study stated the most important factor for maxillofacial trauma is age and followed by sex. The highest incidence at 21-30 years age group, the lowest is more than age 60 or less than 5 years old. Ratio between man and female is 3:1. Ratio of mandibula, zygoma, and maxila fracture is $6: 2: 1.3$

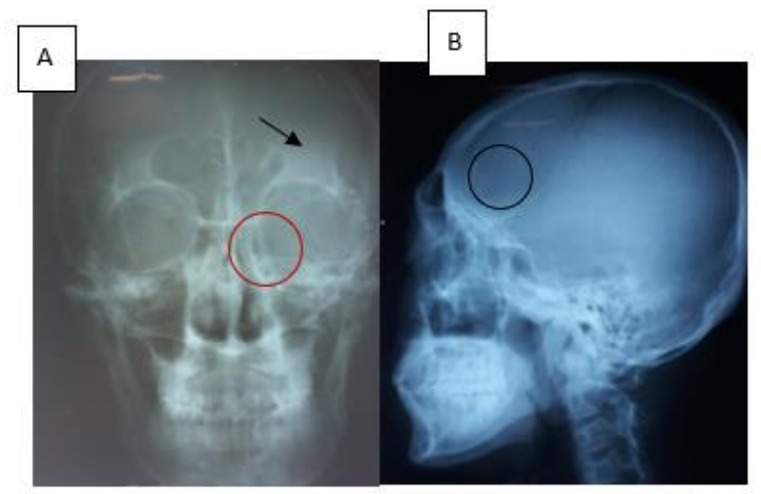

Fig. 9. Skull AP Lateral x-ray showed mini plate on fracture line. (A) mini plate at infraorbital region (circle), frontozygomatic region (arrow). (B) mini plate at frontozygomatic region (circle).

Maxillofacial trauma can cause blowout fracture. Blowout fracture is defined as orbital wall fracture. Sharp object that hit eye bigger than inlet orbit, cause increase of sudden pressure inside orbita, so the most vulnerable site is the base of orbital wall or the medial one. 3 Fracture that occurred at the base and medial or both without orbital rim fracture is known as pure blowout fracture (Fig. 10).

Orbital wall fracture may also accompany with orbital rim fracture. Collision to the eye might be a unison with strong collision to the zygoma bone bulging, so orbital wall fracture (blowout) accompanied by orbital rim fracture. Supraorbital rim consists of frontal bone, while frontal bone articulates with zygoma forming lateral rim (fronto-zygomatic suture), infraorbital rim shaped by zygoma and maxilla (zygomaticomaxillary suture), medial is a complex join of lamina papyrasea, ethmoid, lacrimal bone, maxilla, and prosesus frontal of nasal bone (Orbit, Eyelids, and Lacrimal System, American Academy of Ophthalmology 2015, Leatherbarrow 2011, O’Donnell 2014).

Strong collision to the face may also cause direct fracture to naso-orbital-ethmoid (NOE), this one generally can be happened at procesus frontal fractureblow out bone, lacrimal bone, ethmoid in orbital 
medial wall (Dolan 2005). Blowout fracture with orbital rim fracture is called not pure blowout fracture (Fig. 11).

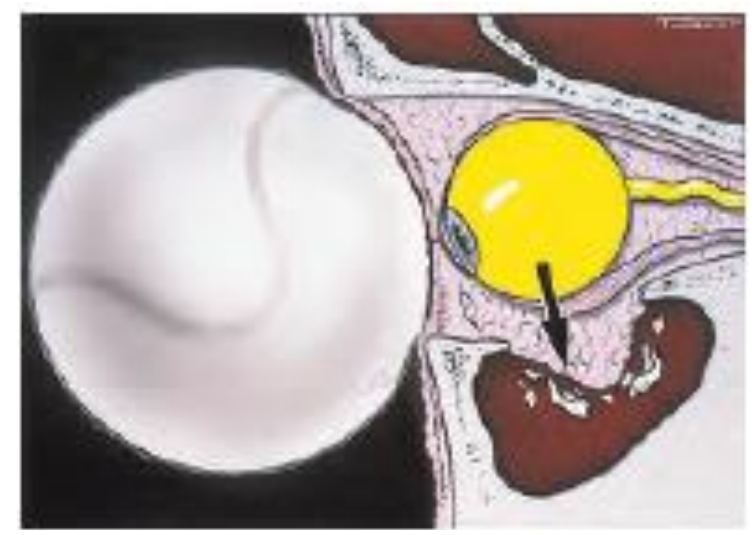

Fig. 10. Pure blowout fracture occurred because of sudden increase of pressure inside orbital will cause fracture in the most vulnerable site, usually at the base or medial orbital wall (Bowling 2016).

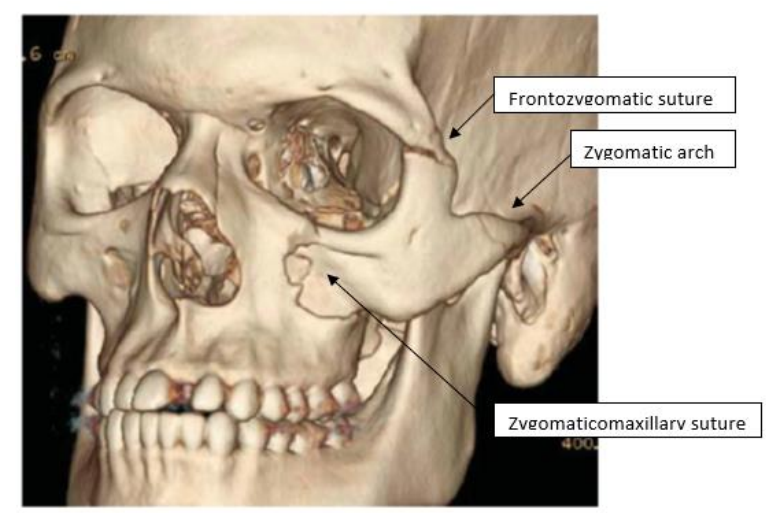

Fig. 11. 3D CT-Scan. Strong collision in the bulge of zygoma arch, so orbital wall fracture at zygoma bone bulging so blowout fracture is accompanied by orbital rim fracture (Humphrey \& Kriet 2014).

First patient had fracture after fell from motorcycle (traffic accident) and left side of the face hit the helmet. Bigger size gave direct impact to the eye ball and left side of orbital rim so blowout fracture happened (orbital base and medial wall/lamina papyrasea) that followed by orbital rim fracture (complex zygomatic, maxilla, nasal bone). For the second case, patient had criminal case where his left side of the face (got hit by wood). It will cause malar protrusion, causing blowout fracture and rim orbital fracture complex type.

Diagnosis blowout fracture is based on anamnesis, physical examination, and other diagnostic tests.
Anamnesis consists of how and when it happened, mechanism of injury, how big the wound is, vision problem, malocclusion history, and bleeding from the nose (Obuekwe et al 2005, Ungari et al 2012).

Physical examination is airway, respiratory and circulation examination. Malar protusion should be sought by observing patient from below. Patient is instructed to open the mouth to try to find trismus. Palpation sould be done carefuly to seek gaps and crepitation. Neurosensorik examination will look for hypoesthesia or anesthesia at eyelid and cheek. X-ray will be needed if fracture is suspected (Obuekwe et al 2005, Ungari et al 2012, Reyes et al 2012).

Other diagnostic tests are paranasal sinus x-ray Waters position to evaluate complex zygomatic fracture. CTscan examination axial, coronal, and sagital will be needed. CT-scan axial plane is useful to evaluate maxillofacial region, while coronal $2 \mathrm{~mm}$ is to evaluate orbital and skull base, and sagitall plane to evaluate trauma. Magnetic resonance imaging (MRI) can be done to evaluate orbital in detail. Evaluation by ophtalmologist is necessary for every orbital fracture patient. The condition of visus, pupil function, eye muscular motility, anterior chamber, and fundus should be known before operation (Humphrey \& Kriet 2014, Susarla \& Peacock 2014, Lee et al 2010).

From history taking, fracture can be occured because of hard and round object collision which are helmet and wood hit, it suited the literature. Collision in first patient is caused by round and big object so the impact not only in orbital inlet but also hit nasal bone and zygomatic complex. The second case, splinter iwas found durante operation so it was stated that the patient not only had collision but also wood hit cause zygomatic complex fracture.

Reyes et al., found 25 from 165 patient who had orbital CT-scan, fracture happened because of physical assault (44\%), fell (32\%), car accident (8\%), and other cause $(16 \%)$. Classification of the fracture is $40 \%$ pure blowout and $60 \%$ complex blowout fracture (Reyes et al 2012).

Physical examination in both patients found deformity of nasal bone and suspicious zygomatic complex fracture so CT-scan is ordered. Crepitation could not be concluded because of oedem and pain while put some pressure in palpation, it showed hypoesthesia in both patients. Both patients still could open their mouths and there is no malocclution. Eye examination found laceration in corneal, scleral, and palpebral accompanied with ecchymosis. It also revealed zero visus and limited eye ball motility. 3D CT-scan showed 
blowout fracture with zygomatic complex, and nasal fracure.

The goal of orbital base fracture management is to give back the funtion of eye muscular and lift up eyeball that goes down. It can be achieved through infraorbital approach (subsiliar, subtarsal, subconjungtiva) that possible to exam orbital base, extract bone fragment, and reconstruct orbital wall using alloplastic implant (Leatherbarrow 2011).

Zygomatic complex fracture usually can be reducted using lever tool (Gilles technique) easily. Bone complex fracture can be put back to its original position trough some approaches (intraoral, temporal or coronal). If zygomatic fracture could not put back to former position or unstable, it is possible because of soft tissue interposition across line fracture or bone fragment. Open reduction and stabilization with wire and mini plate still needs to be done (Leatherbarrow 2011).

Hole is made in frontozygomatic suture for wire fixation about $0,5 \mathrm{~cm}$ above fracture line. Stainless steel wire size 24-gauge is put as simple vertical matras and zygomatic fracture reducted. Bone fragment will mend well when wire tightened eventhough line fracture is untidy. Better choice is using mini plate $(1,5$ or $2,0 \mathrm{~mm})$ trough temporal approach or coronal incision. The advantage of this technique is thin plate but strong and stabil.7 Incision can be choosed between subsiliar, subtarsal, or through conjungtiva (Fig. 12).

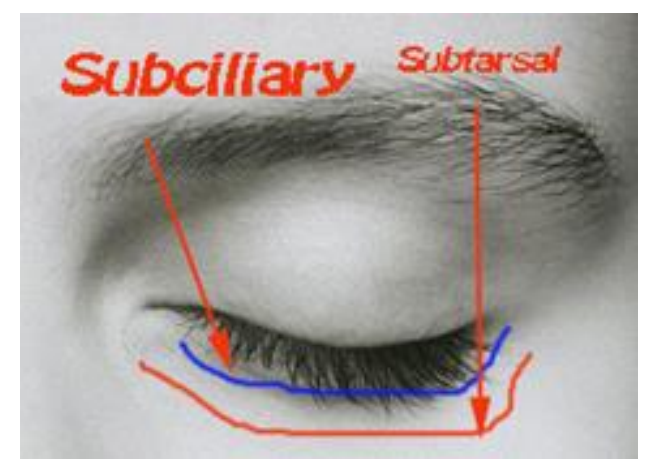

Fig. 12. Variation of incision (Balasubramanian 2010).

Both patients used mini plate size $1,5 \mathrm{~mm}$ at frontozygomatic region and between zygomaticmaxillary and frontomaxillary (procesuss frontal os maxilla) and nasal bone. First patient had it in right side, while the second one in his left side. Mini plate was not screwed at zygomatic arch fracture because it was still stable.
Incision which done at infraorbital region is subtarsal, it leads directly to the fracture location. Next incision is eye brow incision to find line fracture in frontozygomatic. Subtarsal incision can avoid orbicularis oculi musculus, however subciliar incision is better cosmetically. For both patients, incision was done in both region so it can be reducted well, then internal fixation using miniplate can be perfomed. Bonewax is applied before stiching the incision.

Plastic reconstruction division of Ophtalmology departement explored eyeball then doin debridement and sticth palpebral laceration. Anamnesis and visus examination revealed that patient could not see and there was possibility of optical nerve damage due to the trauma.

Both patients were advised to have evisceration and fat (from gluteus) flap implant inside eyeball. First patient refused, the second patient was planned to have eye silicone so the appearence will be better. It was not possible to put silicone eye in the first patient because of atrophy of the eyeball possibility.

\section{CONCLUSION}

Two cases of blowout fracture with rim orbita fracture complex type were managed well at Dr. Soetomo hospital Surabaya by Plastic reconstruction division of ORL-HNS and Plastic reconstruction division of Ophthalmology Department. Multidisciplinary management was required for optimum, result.

\section{REFERENCES}

Balasubramanian T. Blow out fracture (2010). Otolaryngology. Available from: http://www.drtbalu. com/blow_out.html Accessed May 10, 2016

Bowling B (2016). Trauma. In: Bowling B, ed. Kanski’s clinical ophthalmologi a systematic approach. 8th Ed. New South Wales, Elsevier Limited, p 862-85

Dolan RW (2005). Zygomatic Complex and internal orbital fractures. In: Dolan RW, ed. Facial plastic, reconstructive, and trauma surgery. New York, Marcel Dekker, Inc, p 629-70

Humphrey CD, Kriet JD (2014). Orbital fractures. In: Johnson JT, Rosen CA, eds. Bailey's head and neck surgery otolaryngology. 15th Ed. Philadelphia, Lippicott Williams \& Wilkins, p 1225-39

Kentjono WA (2013). Penatalaksanaan trauma maksilofasial. Dalam : Kentjono WA, Wibowo MD. Pendidikan kedokteran berkelanjutan XI. Penataksanaan multidisiplin fraktur maksilofasial. Surabaya, Departemen/SMF Ilmu kesehatan THT-KL 
FK Unair-RSUD Dr Soetomo-Perhati-KL Jawa timur utara, p 1-40

Leatherbarrow B. Zygomatic complex fractures (2011). In: Leatherbarrow B, ed. Oculoplastic surgery. 2nd Ed. London : Informa healthcare, p 547-68

Lee EI, Mohan K, Koshy JC, Hollier LH (2010). Optimizing the surgical management of zygomaticomaxillary complex fractures. Seminar in plastic surgery/volume 24 no 4 2010. Available from http:// www.ncbi.nlm.nih.gov/pmc/articles/PMC3324220/.

Accessed July 18, 2016

O’Donnell B. Orbital trauma (2014). In : Collin R, Rose $\mathrm{G}$, eds. Fundamentals of clinical ophthalmology plastic and orbital surgery. London, BMJ Books, p150-60

Obuekwe O, Oeotade F, Osaiyuwu O, State E, State O (2005). Etiology and pattern of zygomatic complex fractures: a retospective study. Journal of the national medical association 2005. Available from http:// www.etiology_and_pattern_of_zigomatic_complex_fr actures.pdf. Accessed July 18, 2016
Orbit, Eyelids, and Lacrimal System, American Academy of Ophthalmology (2015). Orbital trauma. Basic and Clinical Science Course 2014-2015 7, 95105

Reyes JM, Vargas MFG, Rosenvasser J, Arocena MA, Medina AJ, Funes J (2012). Classification and epidemiology of orbital fractures diagnosed by computed tomography. Head and Neck. Available from http://www.webcir.org/revistavirtual/articulos/ marzo14/argentina/ar_ing.pdf. Accessed July 18, 2016

Susarla SM, Peacock ZS (2014). Zygomaticomaxillary complx fracture. Journal of plastic surgery. Available from http://www.ncbi.nlm.nih.gov/pmc/articles/ PMC4145677/. Accessed July 18, 2016

Ungari C, Filianci F, Riccardi E, Rinna C, Iannetti (2012). Etiology and incidence of zygomatic fraktur: a retrospective study related to a seies of 642 patients. ERMPS. http://www.etiology_and_incidence_of_zigomatic_fractures.pdf. Accesed July 18, 2016 